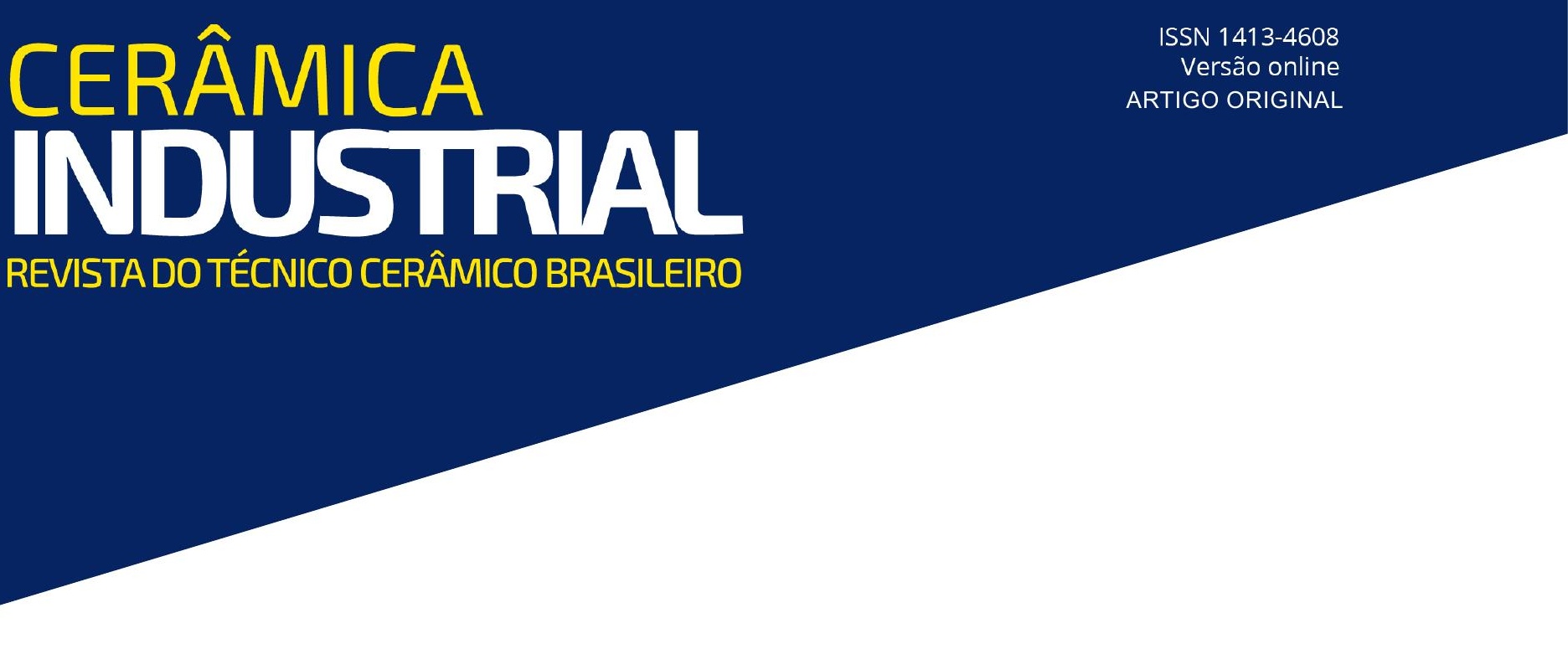

\title{
Efeito da adição de talco dolomítico de jazidas do Piauí como fundente em formulações de massa com argila caulinítica
}

\author{
Pablo Juan Lopes e Silva Santos ${ }^{* 1}$, João Paulo dos Santos Silva1, Roberto Arruda Lima Soares ${ }^{1}$, \\ Érico Rodrigues Gomes ${ }^{1}$ \\ ${ }^{1}$ Programa de Pós-Graduação em Engenharia de Materiais - Instituto Federal de Educação, Ciência e Tecnologia do Piauí - IFPI \\ e-mail: pablojuan.engenhariacivil@gmail.com
}

\begin{abstract}
RESUMO
O estado do Piauí é produtor relevante de materiais cerâmicos tradicionais, a exemplo dos blocos de vedação, blocos estruturais, telhas, lajotas e peças decorativas. Apesar de possuir grandes reservas de minerais argilosos e não argilosos, não existe produção de revestimentos cerâmicos em escala industrial no estado. Este trabalho teve como objetivo avaliar a aplicabilidade do uso de matéria-prima não plástica em formulações com argila natural, para fabricação de revestimentos cerâmicos. Foram confeccionadas cinco formulações de massa cerâmica com a utilização de argila caulinítica e talco dolomítico. Todas estas matérias-primas foram coletadas em jazidas localizadas no estado do Piauí. Estas foram caracterizadas através de análise granulométrica, análise química, análise mineralógica e análise termogravimétrica. Os corpos de prova foram produzidos através de prensagem uniaxial de 20 gramas de material colocados em uma matriz de conformação metálica de dimensões $80 \mathrm{~mm} \times 10 \mathrm{~mm} \times 10 \mathrm{~mm}$, e queimados nas temperaturas de $1000^{\circ} \mathrm{C}, 1100^{\circ} \mathrm{C}$ e $1200^{\circ} \mathrm{C}$. Foram avaliadas as propriedades tecnológicas de retração linear, absorção de água e resistência à ruptura por flexão. Os melhores resultados foram observados nos corpos de prova com adição de talco e queimados na temperatura de $1200^{\circ} \mathrm{C}$, obtendo-se módulo de resistência à flexão máximo de 39,92 MPa e absorção de água de 4,13\%, o que permitiu sua classificação como revestimento cerâmico do tipo Blla. Assim, foram validadas as potencialidades das matérias-primas disponíveis no estado do Piauí para a produção industrial de revestimentos cerâmicos de qualidade.
\end{abstract}

PALAVRAS-CHAVE: Revestimento cerâmico, talco, argila caulinítica, propriedades tecnológicas

\section{INTRODUÇÃO}

O setor cerâmico brasileiro ocupa, desde 2016, o posto de terceiro maior produtor e consumidor de revestimentos cerâmicos, ano em que perdeu a vice-liderança para a crescente indústria indiana (ANFACER 2017). A China mantém a liderança do mercado global desde 2006, com ampla margem das demais nações (CONSTANTINO et al., 2006). No ano de 2017, o Brasil produziu 790 milhões de metros quadrados de revestimentos, de uma capacidade total de produção de 1.055 milhões de metros quadrados.

Atualmente composto por 93 empresas, o setor de revestimentos está mais concentrado nas regiões Sul e Sudeste, porém com franca expansão no Nordeste. O Piauí, pelo contrário, encontra-se 
com sua produção estagnada. A falta de pesquisas e consequentemente um menor conhecimento dos estratos mais internos do solo dificulta a alavancagem do setor, apesar da grande quantidade de jazidas inexploradas que o estado possui (CPRM, 2006). A simples utilização de argila já não é mais suficiente para concorrer num mercado que é crescente e cada vez mais exigente. É essencial a utilização de matérias-primas não plásticas, a exemplo do talco, com a finalidade de minorar perdas e custos, associado a um controle cada vez maior no processo produtivo para garantir os requisitos mínimos de qualidade técnica e estética (SOARES, 2010). No estado do Piauí, estão presentes as províncias geotectônicas Borborema, São Francisco, Costeira e Parnaíba. Esta, também conhecida como Província Sedimentar do Meio Norte, recobre quase a totalidade do estado com a sequência litológica da Bacia do Parnaíba. Nesta região, os solos são resultado da decomposição de rochas sedimentares majoritariamente paleozoicas, formando argissolos, gleissolos sálicos, neossolos flúvicos, neossolos litólicos e neossolos quartzarênicos (PFALTZGRAFF, 2010). Nas faixas aluvionares das formações Piauí, Pimenteiras, Longá e Pedra de Fogo, encontram-se argilas que servem de base para a indústria tradicional de cerâmica vermelha, onde prevalece a produção de tijolos e telhas comuns, e de cerâmica branca.

No sudoeste piauiense, área de domínio da província da Borborema, já são encontradas unidades mais antigas, que datam do mesoarqueano ao neo-arqueano. Estão presentes ali grandes reservas de minerais não argilosos, que podem ser incorporados ao processo de fabricação de revestimentos cerâmicos (CPRM, 2006).

O talco é uma destas matérias-primas não plásticas com grandes jazidas no estado, e que possui excelente aplicabilidade em formulações de massa cerâmica, proporcionando modificações na fundência de compósitos, redução da temperatura de vitrificação, formação de novas fases cristalinas e aumento da resistência à flexão dos produtos, conforme mostram os resultados das pesquisas de Marino et al. (2000) e Vieira et al. (2008). Segundo Rodrigues Neto et al. (2014), além da formação de diopsita $\left[\mathrm{CaMg}\left(\mathrm{SiO}_{2} \mathrm{O}_{6}\right)\right]$, a adição de talco nas formulações promove também o surgimento da fase cristalina enstatita ( $\mathrm{MgO} \cdot \mathrm{SiO}_{2}$ ), resultante da desidroxilação do mineral. Llop et al. (2011) concluiu que com a formação de fase vítrea de menor viscosidade proporcionada pela adição de talco, o quartzo consegue se dissolver de maneira mais rápida na matriz cerâmica, possibilitando a formação de novas fases cristalinas resultantes de seu polimorfismo. Marino et al. (2000) explica que a adição do talco em formulações de massa cerâmica provoca um aumento inicial da retração linear de queima seguido de uma diminuição da absorção de água. Porém, com o aumento progressivo dos percentuais incorporados de talco, a retração linear diminui consideravelmente. Isto se deve ao comportamento da expansão térmica do talco em temperaturas mais elevadas. Acima de $1000^{\circ} \mathrm{C}$ verifica-se uma inflexão nas curvas, com redução do coeficiente de expansão térmica $\alpha$. O talco pode ser encontrado na natureza associado à clorita, serpentita, calcita, quartzo e dolomita. De acordo com Soares (2016), a presença deste carbonato na massa do revestimento proporciona uma porosidade mais adequada das peças durante a sinterização. Portanto, durante o processo de descarbonização da dolomita presente no talco, os óxidos de cálcio e magnésio reagem com as fases amorfas, principalmente sílica e alumina, formando novas fases cristalinas à base de cálcio e magnésio, responsáveis pelas propriedades tecnológicas do produto final (SOUSA \& HOLANDA, 2006).

A escolha do tipo de argila é fundamental para o desenvolvimento de revestimentos cerâmicos. Neste trabalho, foi utilizada uma argila caulínitica como matéria-prima base das formulações. Estas, de acordo com Andrade et al. (2005), por possuírem baixo percentual de óxidos alcalinos fundentes, a exemplo de $\mathrm{K}_{2} \mathrm{O}$ e $\mathrm{Na}_{2} \mathrm{O}$, possuem elevada perda ao fogo. Segundo Marino \& Boschi (1998), as argilas cauliníticas possuem forte tendência à formação de fase cristalina mulita durante a queima, resultando em baixas dilatações térmicas. Isto é explicado pelo baixo coeficiente de expansão térmica $\alpha$ da mulita. De acordo com sua estrutura cristalina, as caulinitas podem se apresentar com elevada, média e baixa desordem estrutural ao longo do eixo b (GARDOLINSKI et al., 2003). CORRÊA et al. (2008) especifica que as caulinitas com estrutura monoclínica apresentam maior desordem estrutural em relação as de estrutura triclínica, denominando o aumento da desordem das argilas como caráter monoclínico.

Outro constituinte importante nos revestimentos cerâmicos é o quartzo. O quartzo é caracterizado pelo seu brilho vítreo, fratura concoidal e forma cristalina. Não é exagero afirmar que existem 
inúmeras formas diferentes de quartzo, para as quais nomes variados têm sido aplicados (KLEIN \& DUTROW, 2012). Biffi (2002) afirma que mesmo com o aumento da temperatura, o quartzo mantém sua estrutura, ao contrário das argilas, caulins e feldspatos que amolecem, ou seja, o quartzo atua como um regulador da plasticidade do sistema, equilibrando as relações entre sílica e alumina, sendo essencial para a formação da fase cristalina mulita. Apesar de atuar no melhoramento de importantes parâmetros de resistência das cerâmicas, o quartzo é uma matéria-prima de baixo custo, portanto bastante acessível. Porém, em temperaturas muito elevadas, o quartzo sofre polimorfismo e possibilita a formação de novas fases cristalinas. Em formulações de massa cerâmica, sua dissolução na matriz também possibilita a recombinação com átomos dos outros constituintes, formando fases cristalinas de outras fórmulas químicas. O quartzo possui elevado coeficiente de expansão térmica, com $\alpha=120$ $\times 10^{7}{ }^{\circ} \mathrm{C}^{-1}$, ao contrário da anortita $\left(\mathrm{Ca}\left(\mathrm{Al}_{2} \mathrm{Si}_{2} \mathrm{O}_{8}\right)\right.$, por exemplo, que é uma fase resultante da reação entre $\mathrm{SiO}_{2}$ (quartzo) e óxido de cálcio (CaO), que possui um médio coeficiente de expansão térmico, $\operatorname{com} \alpha=43 \times 10^{7}{ }^{\circ} \mathrm{C}^{-1}$ (MARINO \& BOSCHI, 1998).

Assim, o objetivo deste trabalho foi analisar a influência da adição de talco na fabricação revestimentos cerâmicos, através da caracterização das matérias-primas, oriundas de jazidas do estado do Piauí, e dos corpos de prova das formulações de massa, comparação das propriedades tecnológicas obtidas e correlação das propriedades mecânicas com as características microestruturais, após a queima em três temperaturas diferentes.

\section{MATERIAIS E MÉTODOS}

Neste trabalho experimental foram utilizadas como matérias-primas uma argila caulinítica proveniente de Cocal de Telha-PI e um talco coletado no município de Dirceu Arcoverde-PI. Para a caraterização das matérias-primas foram utilizados ensaios de granulometria, em que se seguiu o método de peneiramento descrito na ABNT NBR 7181 (2018), em que foram utilizadas cinco peneiras ordenadas da mais grossa (peneira com abertura de $0,180 \mathrm{~mm}-\mathrm{n}^{\circ} 80$ ) para a mais fina (peneira com abertura de $0,045 \mathrm{~mm}-\mathrm{n}^{\circ} 325$ ). Após, foi determinada a plasticidade da argila através dos limites de Atterberg, limite de liquidez (LL) e limite de plasticidade (LP), de acordo com as NBR's 6459 (2017) e 7180 (2017) da ABNT. Através da difração de raios X foram identificadas as fases cristalinas presentes nas matérias-primas utilizadas. Este ensaio foi realizado no equipamento da Shimadzu, modelo XRD6000 , trabalhando com radiação de Cobre (Cu-Ka), tensão de $40 \mathrm{kV}$, corrente de $45 \mathrm{~mA}$ e varredura de $2 \theta$ variando de 6 a $90^{\circ}$, com velocidade de $2^{\circ} / \mathrm{min}$. As amostras do tipo pó foram preparadas para o ensaio através secagem em estufa, moagem por 10 horas em moinho de bolas e peneiração em peneira de $\mathrm{n}^{\circ} 200$.

Foi realizada também a análise da composição química das matérias-primas - argila e talco - através de espectroscopia por fluorescência de raios $X$ em espectrômetro da marca Panalytical, modelo Epsilon $3 \mathrm{XL}$. Com base nos resultados de fluorescência de raios $X$ e difração de raios $X$, foi realizada a análise racional das matérias-primas utilizando o software para análise racional de argilominerais "Quantfases", desenvolvido no IFPI por Silva (2015).

Conclui-se a caracterização das matérias-primas com a análise térmica, em que foi utilizado o Analisador Termogravimétrico TGA-51H Shimadzu. Para os dois tipos de análise, foram utilizadas massas em torno de $15 \mathrm{mg}$, com granulometria inferior a 325 mesh, sob um fluxo de ar sintético de $50 \mathrm{~mL} / \mathrm{min}$. A taxa de aquecimento foi de $10^{\circ} \mathrm{C} / \mathrm{min}$ entre $21^{\circ} \mathrm{C}$ e $1200^{\circ} \mathrm{C}$. A análise dos resultados e a obtenção da curva derivada da TGA denominada DTGA, foram realizadas utilizando o programa de computador denominado TA-60, para análises térmicas da Shimadzu.

Após a caracterização, foi iniciada a preparação das massas cerâmicas. Inicialmente, as matériasprimas em estado bruto foram desagregadas em triturador para tornar a granulometria da argila menos grosseira e promover a trabalhabilidade do talco, inicialmente em formato de rocha. Logo após, os materiais foram submetidos à secagem em estufa à temperatura de $110^{\circ} \mathrm{C}$ por um período de 24 horas. Cumprida a etapa de secagem, as matérias-primas foram moídas a seco, separadamente, em um moinho de bolas para reduzir ainda mais o tamanho das partículas. Após a etapa de moagem, o material resultante foi peneirado diretamente em peneira de $n^{\circ} 80(0,180 \mathrm{~mm})$ da ABNT. Com 
a obtenção da granulometria desejada, menor ou igual a $0,18 \mathrm{~mm}$, foi realizada a confecção das formulações dos corpos de prova de acordo com os percentuais definidos. As amostras foram pesadas com ajuda de uma balança digital OHAUS Adventurer modelo ARA520, com precisão de 0,1 $\mathrm{g}$ e a partir de então, foram realizadas as misturas entre as matérias-primas através de moagem a seco e posterior granulação da massa com teor de umidade em $10 \%$, resultando num total de cinco formulações, mostradas na tabela 1, abaixo.

Tabela 1 - Formulações das massas cerâmicas

\begin{tabular}{ccc} 
Formulações das massas cerâmicas & \multicolumn{2}{c}{ Concentração em peso (\%) } \\
\cline { 2 - 3 } A & Argila & Talco \\
T5 & 100 & 5 \\
T10 & 95 & 10 \\
T15 & 90 & 15 \\
T20 & 85 & 20 \\
\hline
\end{tabular}

Fonte: Dados da pesquisa (2019).

Para cada formulação foram confeccionados 33 corpos de prova, sendo seis para cada uma das três temperaturas de queima para a realização dos ensaios mecânicos, seis corpos para secagem, três corpos para queima em três temperaturas diferentes para posterior análise em DRX e seis corpos de prova reservas em caso de problemas, totalizando 165 corpos de prova. Após a etapa de homogeneização, as massas cerâmicas de cada formulação foram pesadas em quantidades de 20 gramas e colocadas em uma matriz de conformação metálica com dimensões de $80 \times 10 \times 10 \mathrm{~mm}$ (comprimento, largura e espessura). Após a correta montagem da matriz metálica com a massa cerâmica inserida, foi realizada prensagem uniaxial em uma prensa hidráulica da fabricante Ribeiro, modelo RP0002, com pressão de compactação de $35 \mathrm{MPa}$.

Realizada a confecção dos corpos de prova, estes foram colocados em estufa a uma temperatura de $110^{\circ} \mathrm{C}$, durante um intervalo de tempo de 24 horas. Após a secagem, os corpos de prova secos tiveram suas dimensões medidas através de paquímetro digital Zaas, modelo 10014. Logo após, foram pesados em balança de precisão digital e os valores encontrados foram utilizados para o cálculo da densidade a verde dos corpos de prova. O valor do comprimento inicial foi utilizado para posterior determinação da retração linear de queima. Posteriormente ao fim da secagem, os corpos de prova foram queimados em forno do tipo mufla da marca EDG, modelo F1800, do laboratório GERATEC/UESPI, nas temperaturas de $1000^{\circ} \mathrm{C}, 1100^{\circ} \mathrm{C}$ e $1200^{\circ} \mathrm{C}$. A queima ocorreu por meio de uma taxa de aquecimento constante de $10^{\circ} \mathrm{C} / \mathrm{min}$, na qual os corpos de prova foram mantidos na máxima temperatura com um tempo de patamar de 60 minutos. O resfriamento dos corpos ocorreu de forma natural até a temperatura ambiente ser atingida. Após a queima, foram realizados ensaios para determinação das propriedades tecnológicas de Retração Linear de Queima (RLQ), Absorção de Água (AA), através do método da fervura, Módulo de Resistência à Flexão (MRF), e caraterização microestrutural através de microscopia óptica e ensaio de difração de raios $X$ (DRX).

\section{RESULTADOS E DISCUSSÕES}

\subsection{Caracterização das matérias-primas}

A análise da distribuição granulométrica da argila revelou um elevado número de finos, que proporciona um bom empacotamento na etapa de prensagem. Este resultado é devido ao eficaz processo de moagem, possibilitando uma maior interação entre as partículas e possivelmente uma menor temperatura durante a sinterização. Essa granulometria foi fundamental para analisar a viabilidade do talco como fundente, pois promoveu uma maior reatividade entre os óxidos de cálcio e magnésio e as fases amorfas procedentes da decomposição dos argilominerais, formando novas fases cristalinas e evitando a expansão por umidade. A tabela 2 ilustra estes resultados. 
EFEITO DA ADIÇÃO DE TALCO DOLOMÍTICO DE JAZIDAS DO PIAUÍ COMO FUNDENTE EM FORMULAÇÕES DE MASSA COM ARGILA CAULINÍTICA

Santos, P. J. L. S. et al.

Tabela 2 - Distribuição granulométrica das matérias-primas

\begin{tabular}{cccc}
\hline Peneira da ABNT & Abertura $(\mathbf{m m})$ & Argila retida (\%) & Talco retido (\%) \\
80 & 0,180 & 3,84 & 2,35 \\
100 & 0,150 & 2,53 & 48,74 \\
120 & 0,125 & 1,58 & 5,67 \\
170 & 0,090 & 3,29 & 19,34 \\
200 & 0,075 & 1,64 & 4,49 \\
325 & 0,045 & 2,94 & 12,73 \\
Fundo & & 84,18 & 6,68 \\
Total & & 100 & 100 \\
\hline
\end{tabular}

Fonte: Dados da pesquisa (2019).

Através da determinação dos diâmetros efetivos, d60 e d10, correspondentes a $60 \%$ e $10 \%$ do material passante, das duas matérias-primas, foram calculados os coeficientes de uniformidade $(\mathrm{Cu})$ da argila e talco, através da razão entre d60 e d10.

Com os diâmetros obtidos através das linhas de referência traçadas no gráfico da figura 1 , obtiveram-se os valores de $\mathrm{Cu}=1,00$, para a argila, que indica solo perfeitamente uniforme e $\mathrm{Cu}=$ 3,69 para o talco. Portanto, todos os valores observados obedeceram à condição de $\mathrm{Cu}<5,0$, que segundo Allen-Hazen (1905), indica a presença de material com granulometria muito uniforme, conforme representado na figura 1.

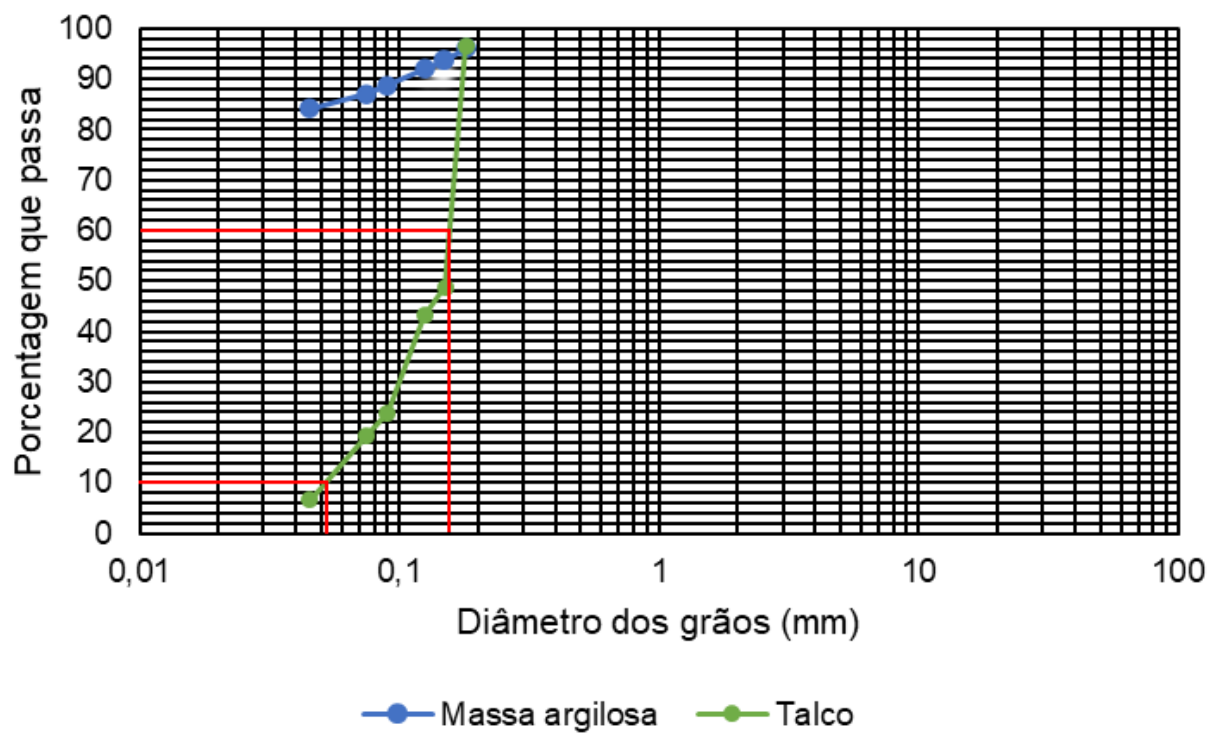

Fig. 1. Curva granulométrica das matérias-primas

Através da fluorescência de raios $X$, foi realizada a análise química das matérias-primas utilizadas no trabalho. A tabela 3 mostra que a argila apresentou em sua composição química um percentual majoritário de SiO2 (53,15\%), óxido responsável pela vitrificação e composição das fases cristalinas após a queima. De acordo com Santos (1989), a sílica livre contribui para a diminuição da retração linear, aumentando a estabilidade dimensional das peças para fabricação de revestimento cerâmico. A presença de óxido de alumínio, com percentual de 39,17\%, é importante para a obtenção de propriedades tecnológicas, pois os átomos de alumínio são essenciais para a formação, em combinação com outros elementos, das fases cristalinas anortita $\left(\mathrm{CaAl}_{2} \mathrm{SiO}_{8}\right)$ e mulita $\left(3 \mathrm{Al}_{2} \mathrm{O} 3 \cdot \mathrm{SiO}_{2}\right)$, após a queima. Na tabela 3 é mostrada também a composição química do talco, que além do $\mathrm{CaO}(35,70 \%)$, imprescindível para a formação de anortita, possui grande quantidade de $\mathrm{MgO}(29,57 \%)$, que juntamente com o alumínio, poderá favorecer a formação de Espinélio (MARINO \& BOSCHI, 1998a). 
Tabela 3 - Composição química das matérias-primas

\begin{tabular}{cccccccc}
\multirow{2}{*}{ Amostra } & $\mathbf{S i O}_{2}$ & $\mathbf{A l}_{\mathbf{2}} \mathbf{O}_{\mathbf{3}}$ & $\mathbf{F e}_{\mathbf{2}} \mathbf{O}_{\mathbf{3}}{ }^{*} / \mathbf{M g} \mathbf{O}^{* *}$ & $\mathbf{T i O}_{2}$ & $\mathbf{K}_{\mathbf{2}} \mathbf{O}$ & $\mathbf{P}_{\mathbf{2}} \mathbf{O}_{\mathbf{5}}$ & $\mathbf{C a O}$ \\
\cline { 2 - 8 } Argila & 53,15 & 39,17 & $4,02^{*}$ & 2,42 & 0,66 & 0,41 & 0,17 \\
Talco & 35,70 & 30,53 & $29,57^{* *}$ & 2,33 & 1,16 & 0,28 & 0,43 \\
\hline
\end{tabular}

Fonte: Dados da pesquisa (2020).

A figura 2 mostra que as fases cristalinas identificadas no difratograma da argila foram referentes à caulinita $\left(\mathrm{Al}_{2} \mathrm{Si}_{2} \mathrm{O}_{5}(\mathrm{OH})_{4}\right)$ e quartzo $\left(\mathrm{SiO}_{2}\right)$, corroborando com os resultados da fluorescência de raios $\mathrm{X}$. Com um percentual de óxidos fundentes $\left(\mathrm{CaO}\right.$ e $\left.\mathrm{K}_{2} \mathrm{O}\right)$ abaixo de $1 \%$, verifica-se um indicativo de formação de fase líquida, durante a queima, somente em temperaturas mais elevadas.

Assim, a caulinita confere um comportamento refratário à massa cerâmica, e o quartzo se comporta como o esqueleto da peça cerâmica durante a fase líquida, diminuindo a retração da massa. Além do pico principal, característico da caulinita e com distância interplanar $d=7,15 \AA$, foram verificados os

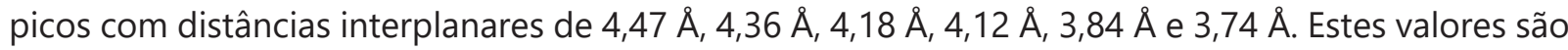
suficientes para classificar a caulinita como bem cristalizada de acordo com o critério estabelecido por Santos (1989). Esta característica é muito importante, pois indica maior facilidade das caulinitas em formar fases cristalinas de maior resistência mecânica.

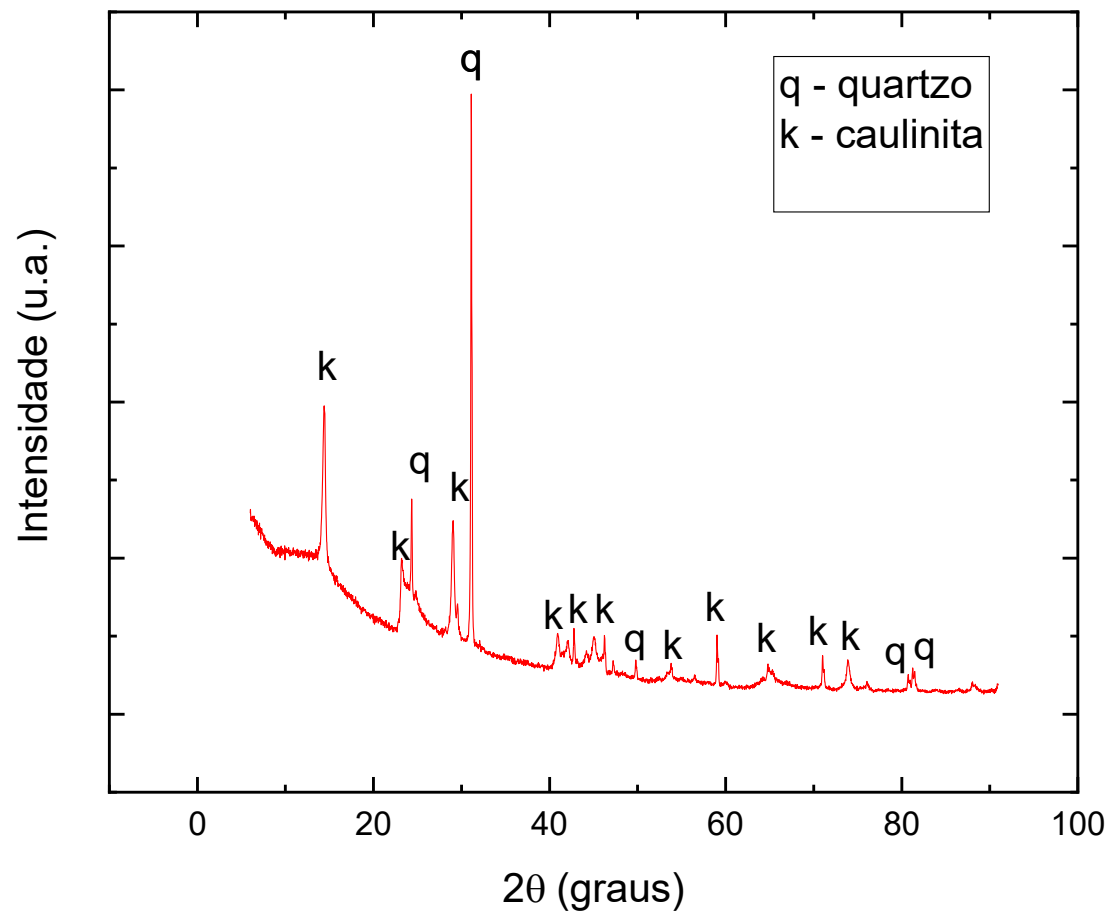

Fig. 2. Análise mineralógica da argila

No talco, foram identificados picos referentes às estruturas cristalinas da dolomita $\left(\mathrm{CaMg}\left(\mathrm{CO}_{3}\right)_{2}\right)$ e do próprio talco $\left(\mathrm{Mg}_{3} \mathrm{Si}_{4} \mathrm{O}_{10}(\mathrm{OH})_{2}\right)$, componente majoritário deste mineral. O pico de maior intensidade presente no difratograma é o da dolomita, e os outros dois de maior magnitude são referentes ao talco, e isto permitiu classificar o mineral como talco dolomítico (SANTOS, 1989). Em algumas aplicações industriais do talco, a dolomita é considerada uma impureza prejudicial e que deve ser eliminada. Isso é exigido, por exemplo, na utilização do talco em produtos de perfumaria e cosméticos. A dolomita, por ser uma substância abrasiva, deve ser eliminada do mineral. Estas restrições não se justificam nas aplicações da indústria de revestimentos, em que a presença de dolomita é algo desejável para a melhoria das caraterísticas dos produtos. A figura 3 mostra a identificação dos picos após ensaio de DRX. 


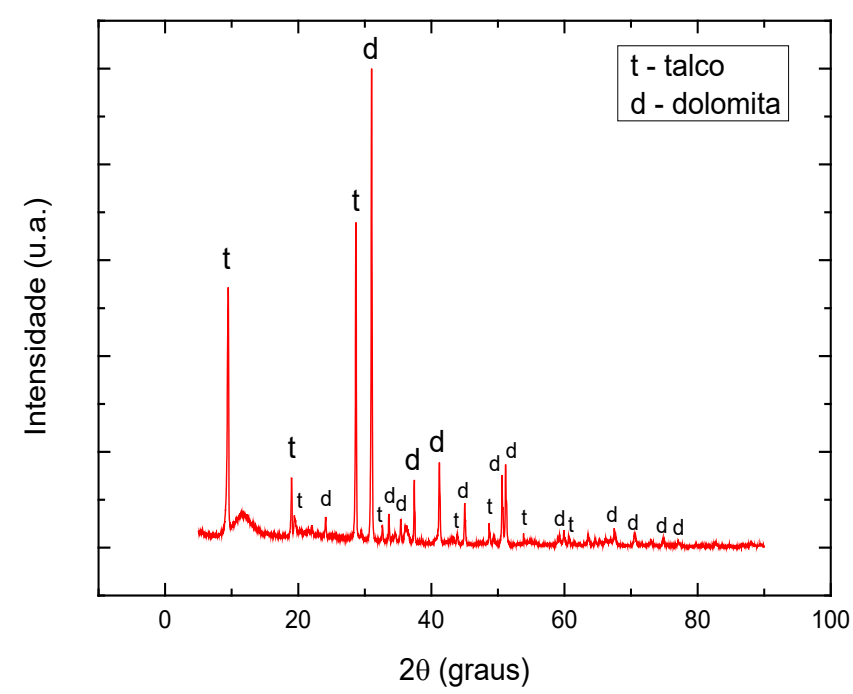

Fig. 3. Análise mineralógica do talco

Após análise da curva termogravimétrica (TGA) e da derivada da curva termogravimétrica (DTGA) da argila, verificou-se uma perda de massa de $1,23 \%$ até o pico de $231,87^{\circ} \mathrm{C}$, correspondente à perda da água adsorvida, característica típica das argilas cauliníticas. Além do pico já mencionado, foi verificado também um evento a $28,53^{\circ} \mathrm{C}$. Ambos são de natureza endotérmica, o que de acordo com Santos (1989), explica a saída da água após a quebra de suas ligações devido à absorção de energia. O terceiro evento ocorreu a $543,76^{\circ} \mathrm{C}$, que representa o ponto máximo de perda de hidroxila da estrutura dos argilominerais, resultante da formação de metacaulinita, com perda de massa de $6,27 \%$. Deste ponto até $1200^{\circ} \mathrm{C}$, segue-se com a liberação de $\mathrm{OH}$ e posteriormente a nucleação de mulita, totalizando uma perda de massa de $4,96 \%$. A perda de massa total foi de $12,53 \%$. A figura 4 mostra o resultado da análise térmica da argila.

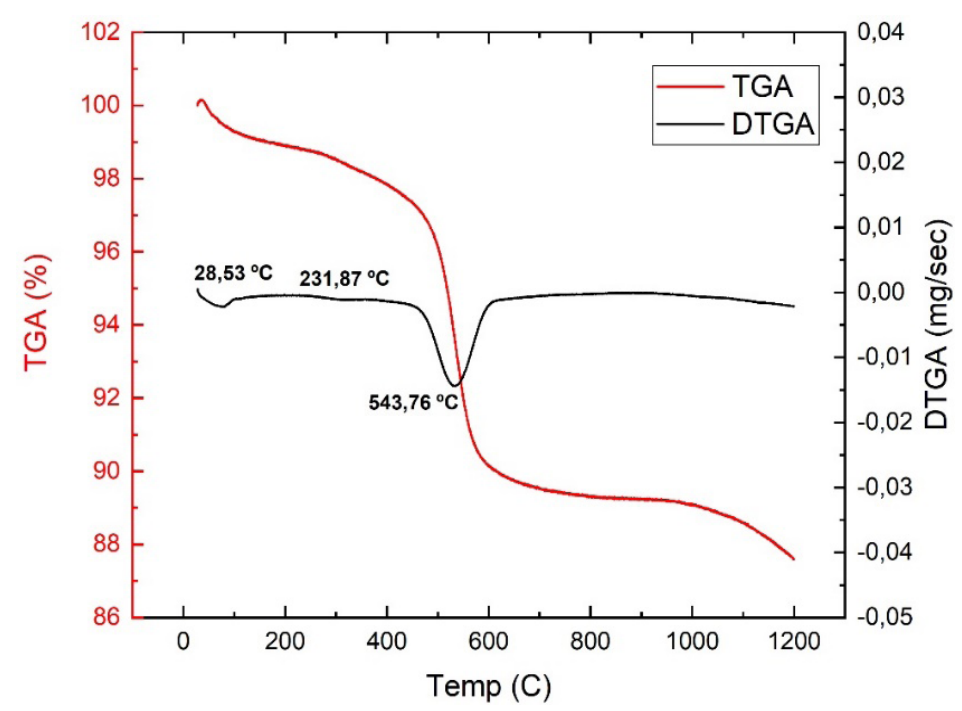

Fig. 4. TGA e DTGA da argila

Ao analisar a curva TGA do talco, mostrada na figura 4, verificou-se uma perda de massa total de $34,43 \%$. Este valor está associado principalmente à eliminação de $\mathrm{CO}_{2}$ resultante da descarbonização da dolomita, que está presente em grande quantidade no mineral (SANTOS, 1989). Como pode ser observado na curva DTGA, na temperatura de $81,75^{\circ} \mathrm{C}$ ocorre um evento relacionado a eliminação 
de água livre do talco. Verificou-se, também, um pico endotérmico na temperatura de $836,45^{\circ} \mathrm{C}$ referente aos eventos de liberação de $\mathrm{CO}_{2}$ da dolomita e desidroxilação do talco, que promove a formação de enstatita.

A dolomita, por possuir em sua composição carbonatos de cálcio e magnésio, apresenta maior fração carbonática resultante da descarbonização que a calcita e isto explica a progressiva perda de massa mesmo após a temperatura de $1000^{\circ} \mathrm{C}$. Desta temperatura até $1200^{\circ} \mathrm{C}$, a perda de massa chega a 2,46\%, ao contrário do verificado na TGA da calcita. A figura 5 mostra o resultado desta análise térmica até a temperatura de $1200^{\circ} \mathrm{C}$.

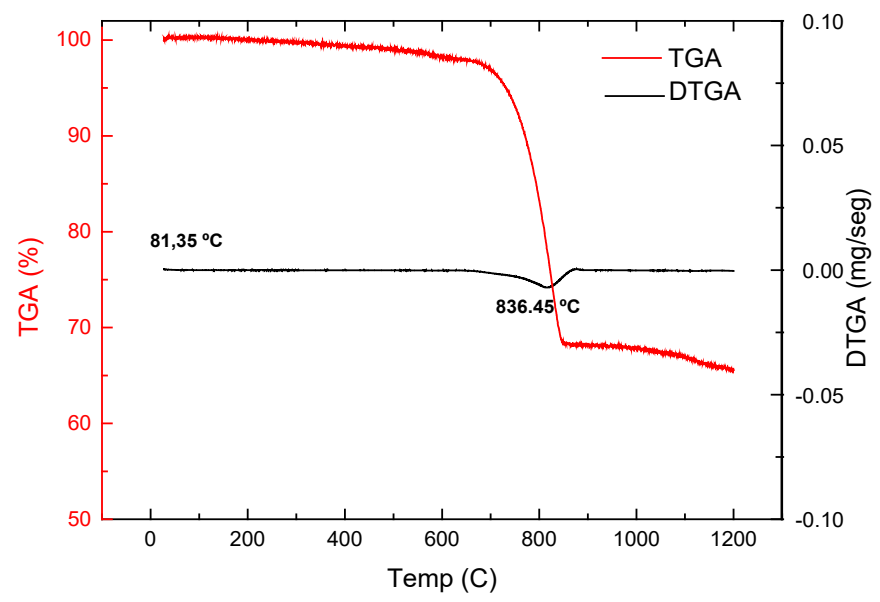

Fig. 5. TGA e DTGA do talco

Os valores obtidos na análise racional mostraram uma predominância da fase cristalina caulinita na argila em relação a fase quartzo, com $92,66 \%$ do total de fases formadas. Essa quantidade expressiva de caulinita revela o grande caráter refratário desta argila, o que irá impactar positivamente nas propriedades tecnológicas dos corpos de prova queimados em temperaturas mais elevadas.

Após a análise racional do talco, verificou-se uma predominância da fase cristalina talco e $42,97 \%$ de dolomita. Estes valores indicam grande tendência de formação de novas fases cristalinas provenientes da decomposição química do talco e da dolomita, que reage fornecendo óxidos de cálcio e magnésio na matriz cerâmica. A tabela 4 reúne os percentuais de fases cristalinas formadas nas matérias-primas utilizadas.

Tabela 4 - Percentual de fases cristalinas nas matérias-primas

\begin{tabular}{ccccc} 
Matérias-primas & \multicolumn{4}{c}{ Fases identificadas (\%) } \\
\cline { 2 - 5 } & Caulinita & Quartzo & Talco & Dolomita \\
Argila & $92,66 \%$ & $7,34 \%$ & - & - \\
Talco & - & - & $57,03 \%$ & $42,97 \%$ \\
\hline
\end{tabular}

Fonte: Dados da pesquisa (2020).

\subsection{Propriedades tecnológicas}

De acordo com o gráfico da figura 6, a formulação A retraiu progressivamente até a temperatura de $1100^{\circ} \mathrm{C}$. Este comportamento é atribuído ao fechamento da porosidade que possibilita uma maior densificação das peças. Nesta faixa de temperatura ocorreu uma perda de massa devido à decomposição da caulinita $\left(\mathrm{Al}_{2} \mathrm{SiO}_{5}(\mathrm{OH})_{4}\right)$, gerando uma maior formação de fase líquida. A $120{ }^{\circ} \mathrm{C}$ a retração sofreu uma leve redução, fato que pode ser explicado pelo início do processo de formação da mulita, que é uma fase cristalina de baixo coeficiente de dilatação térmica. Esta variação não implicou em alterações nos parâmetros de absorção de água e resistência à flexão, conforme explicações posteriores. 
As formulações com talco apresentaram ligeiro aumento na RLQ à temperatura de $1000{ }^{\circ} \mathrm{C}$ em relação à formulação $A$. A explicação para isto é que os corpos de prova com talco apresentaram valores de densidade a seco abaixo da argila pura, proporcionando um aumento inicial da retração linear. Porém, com o aumento da temperatura de queima nas formulações, a partir da temperatura de $1100^{\circ} \mathrm{C}$, acentuou-se a influência do baixo coeficiente de expansão térmica $(\alpha)$ do talco a partir desta faixa térmica, propiciando progressiva redução da retração linear das peças, resultando em expansão. Nesta faixa de temperatura, fica evidente a maior redução na retração das formulações T15 e T20, com os maiores teores de talco. Na temperatura de $1200^{\circ} \mathrm{C}$, todas as formulações sofreram expansão e, novamente, as formulações T15 e T20 apresentaram os maiores percentuais. Isto evidencia a forte correlação entre a adição de talco e o aumento progressivo da expansão nas peças devido a menores valores de $\alpha$, reduzindo a dilatação nos corpos de prova.

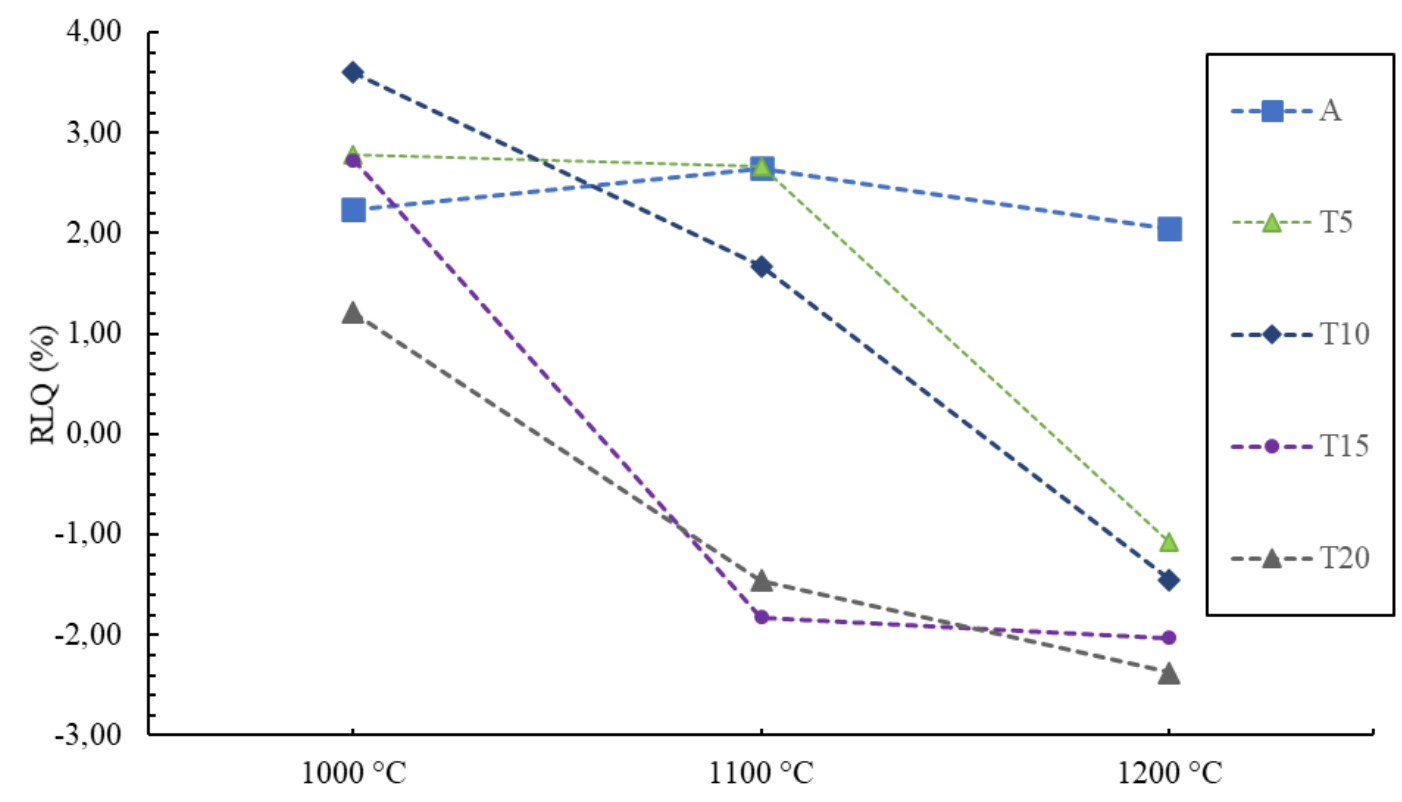

Fig. 6. Retração linear de queima

A tabela 5 mostra os resultados de RLQ obtidos nas três temperaturas de queima utilizadas.

Tabela 5 - Retração linear de queima

\begin{tabular}{cccc} 
& \multicolumn{3}{c}{ RLQ (\%) } \\
\cline { 2 - 4 } Formulações & \multicolumn{3}{c}{ Temperatura ( $\left.{ }^{\circ} \mathbf{C}\right)$} \\
\cline { 2 - 4 } & $\mathbf{1 0 0 0}{ }^{\circ} \mathbf{C}$ & $\mathbf{1 1 0 0}^{\circ} \mathbf{C}$ & $\mathbf{1 2 0 0}{ }^{\circ} \mathbf{C}$ \\
Aw & $2,24 \pm 0,48$ & $2,65 \pm 0,13$ & 0,05 \\
T5 & $2,79 \pm 0,38$ & $2,67 \pm 0,41$ & $-1,07 \pm 0,19$ \\
T10 & $3,60 \pm 0,50$ & $1,67 \pm 0,74$ & $-1,45 \pm 0,06$ \\
T15 & $2,73 \pm 0,38$ & $-1,82 \pm 0,15$ & $-2,03 \pm 0,27$ \\
T20 & $1,21 \pm 0,15$ & $-1.46 \pm 0,51$ & $-2,37 \pm 0,18$ \\
\hline
\end{tabular}

Fonte: Dados da pesquisa (2020).

Do gráfico da figura 7 pode-se observar que a absorção de água da formulação $A$ diminuiu gradualmente até a temperatura de $1100^{\circ} \mathrm{C}$, porém, somente a $1200^{\circ} \mathrm{C}$, uma redução significativa de $56,44 \%$ na AA é verificada, comprovando assim o forte caráter refratário desta argila caulinítica. Nesta, a significativa formação de fase líquida ocorre em temperaturas mais elevadas, iniciando com a liberação cristobalita (SiO2) que irá reagir com os óxidos metálicos livres, formando vidros, até a completa formação da fase cristalina mulita, na temperatura de 1200 C. Isto é comprovado após a análise da difratometria de raios $\mathrm{X}$ desta formulação, mostrado no decorrer deste trabalho. 
Nos corpos de prova com a adição de talco, observaram-se os menores valores de absorção de água à temperatura de $1200^{\circ} \mathrm{C}$. Nas temperaturas de $1000^{\circ} \mathrm{Ce} 1100^{\circ} \mathrm{C}$ os percentuais de AA deste tipo de formulação se manteve, em geral, acima das demais. Como já explicado anteriormente, o óxido de cálcio promove uma maior formação de fase líquida na faixa térmica de $1200^{\circ} \mathrm{C}$. O talco, por possuir carbonatos que em sua decomposição formam, além do óxido de cálcio o óxido de magnésio, promove uma maior vitrificação das peças e a consequente redução da porosidade aberta. Além disso, a análise térmica do talco mostra que o material, entre $1100^{\circ} \mathrm{C}$ e $1200^{\circ} \mathrm{C}$, continua a perder massa, evidenciando o não aprisionamento de $\mathrm{CO}_{2}$ em seu interior. Nestas formulações, a AA ficou abaixo de $6 \%$ em três das quatro formulações, permitindo classificá-las segundo este parâmetro e, de acordo com a NBR ISO 13006, em revestimentos cerâmicos do tipo Blla. Embora a adição de talco tenha colaborado para a redução da porosidade dos corpos de prova, este efeito provocou resultados inversos na retração linear de queima, resultando em expansão. Isto é explicado pela formação de fases cristalinas de baixo coeficiente de expansão térmica nesta faixa de temperatura e consequente diminuição dos teores de quartzo nas peças, que possui elevado coeficiente $\alpha$.

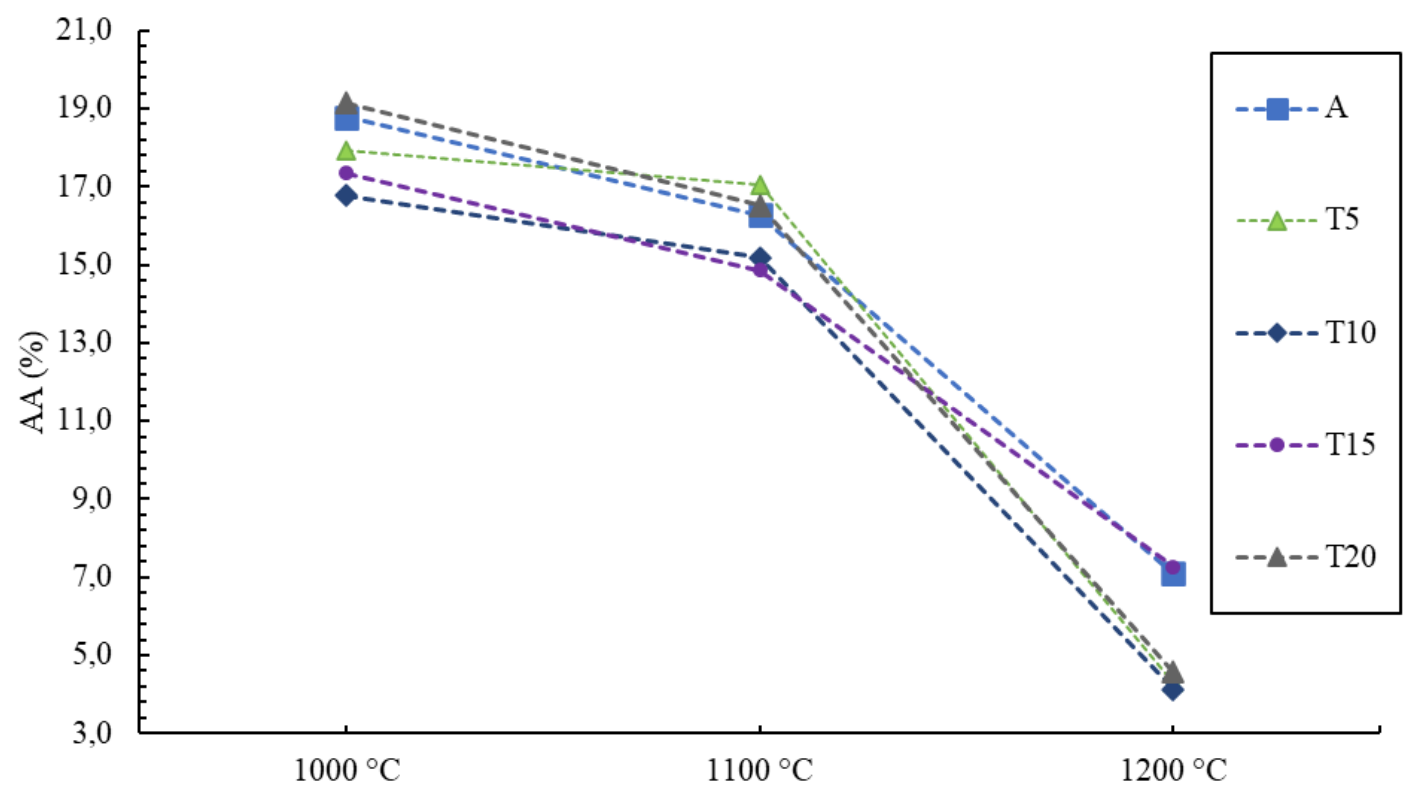

Fig. 7. Absorção de água

A tabela 6 mostra os resultados de AA obtidos nas três temperaturas de queima utilizadas.

Tabela 6 - Absorção de água

\begin{tabular}{cccc} 
& \multicolumn{3}{c}{ AA (\%) } \\
\cline { 2 - 4 } Formulações & \multicolumn{3}{c}{ Temperatura $\left({ }^{\circ} \mathbf{C}\right)$} \\
\cline { 2 - 4 } & $\mathbf{1 0 0 0}{ }^{\circ} \mathbf{C}$ & $\mathbf{1 1 0 0}{ }^{\circ} \mathbf{C}$ & $\mathbf{1 2 0 0}{ }^{\circ} \mathbf{C}$ \\
A & $18,78 \pm 0,15$ & $16,28 \pm 0,41$ & $7,09 \pm 0,10$ \\
T5 & $17,93 \pm 0,51$ & $17,04 \pm 0,36$ & $4,30 \pm 0,23$ \\
T10 & $16,77 \pm 0,24$ & $15,19 \pm 0,12$ & $4,13 \pm 0,14$ \\
T15 & $17,35 \pm 0,49$ & $14,86 \pm 0,29$ & $7,27 \pm 0,39$ \\
T20 & $19,14 \pm 0,53$ & $34,53 \pm 0,19$ & $4,58 \pm 0,25$ \\
\hline
\end{tabular}

Fonte: Dados da pesquisa (2020).

Com o aumento da temperatura, verificou-se um aumento da resistência à flexão em todas as cinco formulações analisadas, mostrando forte correlação com a absorção de água. Porém, o aumento percentual relativo entre as temperaturas de queima variou bastante entre cada tipo de formulação, o que pode ser verificado na figura 8 . Nos corpos de prova da formulação $\mathrm{A}$ o aumento percentual de resistência entre $1000^{\circ} \mathrm{C}$ e $1100^{\circ} \mathrm{C}$ foi de $23,41 \%$ e entre $1100^{\circ} \mathrm{C}$ e $1200^{\circ} \mathrm{C}$, o aumento verificado de 
$52,55 \%$, totalizando um aumento percentual acumulado de 75,96\%. Estes valores são condizentes com o comportamento refratário das argilas cauliníticas, que sofrem uma maior vitrificação em temperaturas mais elevadas. Portanto, nesta faixa térmica, de 1100 a $1200^{\circ} \mathrm{C}$, ainda existe um número considerável de poros a serem preenchidos pela fase líquida formada e isto contribui diretamente para o aumento da resistência. Isto é corroborado com a significativa diminuição da absorção de água de $16,28 \%$ para $7,09 \%$, o que permite classificar este revestimento cerâmico como Bllb na temperatura de $1200^{\circ} \mathrm{C}$.

A exceção da formulação $\mathrm{T} 5$, nas temperaturas de $1000^{\circ} \mathrm{C}$ e $1100^{\circ} \mathrm{C}$, todas as outras formulações com adição de talco apresentaram maior resistência à flexão que a formulação A. Verificaram-se valores de aumento percentual acumulado máximos de $184,92 \%$ e $140,37 \%$, para as formulações T5 e 10, respectivamente. Isto indica que nas formulações com menor adição de talco, os efeitos do aumento da temperatura até $1200^{\circ} \mathrm{C}$ foram bem mais significativos para o aumento das resistências, o que também é explicado pelos percentuais de absorção de água. A formulação T5 obteve 4,30\% de AA e a T10 alcançou um valor de 4,13\%, sendo este o menor entre as formulações do tipo " $\mathrm{T}$ ". Não coincidentemente a formulação T10 obteve a maior resistência à $1200^{\circ} \mathrm{C}$, com $39,92 \mathrm{MPa}$, e a maior aumento percentual relativo desta temperatura de queima, com $75,31 \%$.

Porém, à $1000^{\circ} \mathrm{C} \mathrm{e} 1100^{\circ} \mathrm{C}$, observaram-se os maiores valores de variação percentual relativa em relação a formulação padrão nas formulações T15 e T20, com 22,91\% e 47,39\% respectivamente. Estes valores mostraram que nos corpos de prova confeccionados com os maiores percentuais de talco obtiveram os melhores resultados de MRF em temperaturas mais baixas. Isto revela que a ação dos óxidos de cálcio e magnésio promove uma maior formação de fase líquida nas três temperaturas, e os efeitos são imediatos nas duas primeiras quando o número de poros provenientes da argila refratária ainda é elevado. Porém, a $1200^{\circ} \mathrm{C}$, com uma maior densificação da peça promovida pela decomposição da caulinita, o excesso de $\mathrm{CO}_{2}$ resultante da decomposição dos carbonatos impactou diretamente nos resultados das formulações T15 e T20, resultando em um aumento da porosidade aberta. Isto é corroborado pelos maiores resultados de absorção de água e porosidade aparente verificados.

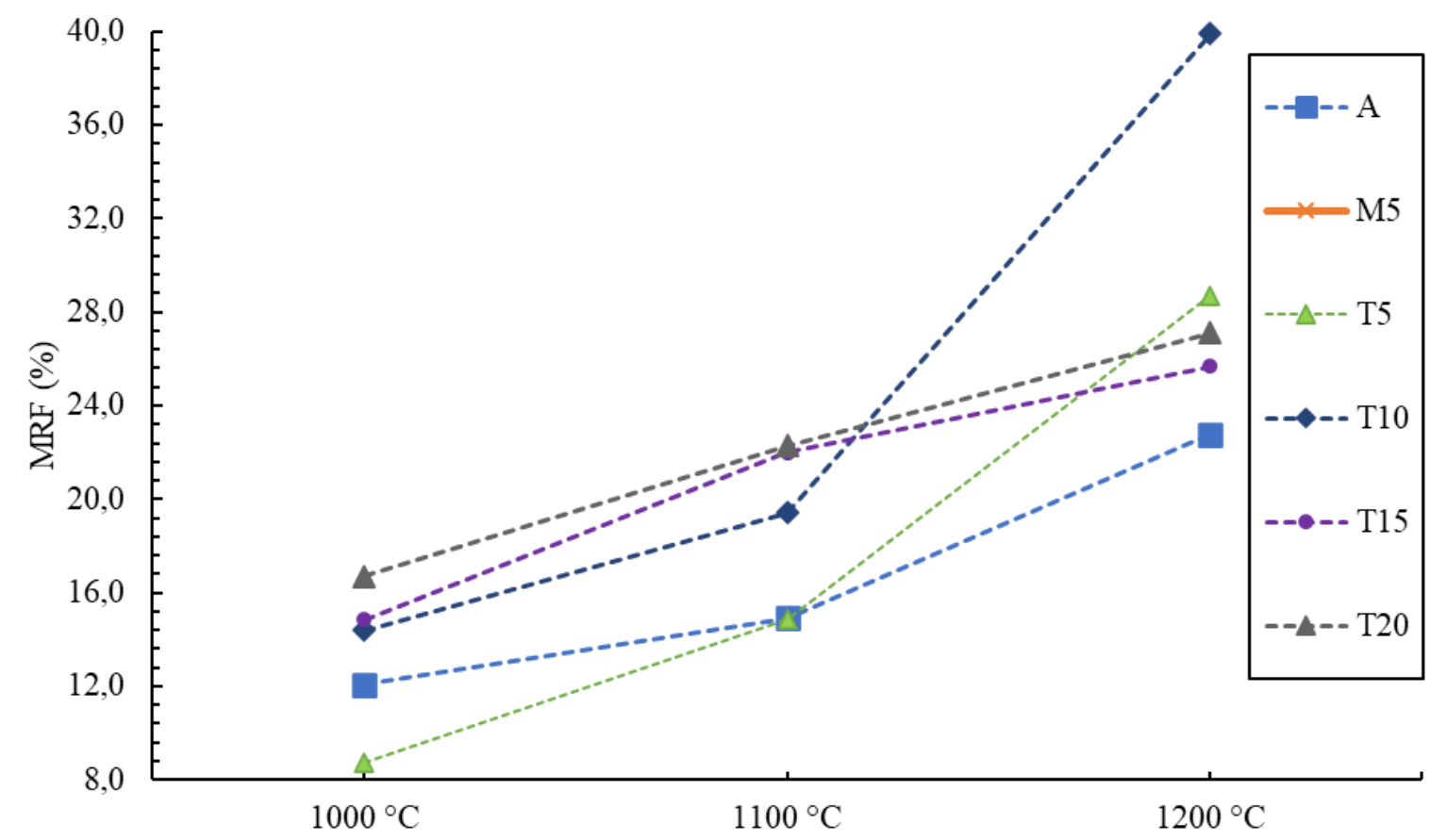

Fig. 8. Módulo de resistência à flexão

A tabela 7 mostra os resultados de MRF obtidos nas três temperaturas de queima utilizadas. 
Tabela 7 - Módulo de resistência à flexão

\begin{tabular}{|c|c|c|c|}
\hline \multirow{3}{*}{ Formulações } & \multicolumn{3}{|c|}{ MRF (MPa) } \\
\hline & \multicolumn{3}{|c|}{ Temperatura $\left({ }^{\circ} \mathrm{C}\right)$} \\
\hline & $1000^{\circ} \mathrm{C}$ & $1100^{\circ} \mathrm{C}$ & $1200^{\circ} \mathrm{C}$ \\
\hline$A$ & $12,09 \pm 0,86$ & $14,92 \pm 1,67$ & $22,76 \pm 1,01$ \\
\hline T5 & $7,74 \pm 1,19$ & $14,85 \pm 0,73$ & $28,67 \pm 0,95$ \\
\hline T10 & $14,39 \pm 0,66$ & $19,43 \pm 0,30$ & $39,92 \pm 0,75$ \\
\hline T15 & $14,86 \pm 0,41$ & $21,99 \pm 0,12$ & $25,68 \pm 0,82$ \\
\hline T20 & $16,71 \pm 1,59$ & $22,27 \pm 1,09$ & $27,11 \pm 1,16$ \\
\hline
\end{tabular}

Fonte: Dados da pesquisa (2020).

Para proporcionar uma melhor análise entre as propriedades tecnológicas verificadas nas diferentes formulações, definiu-se um número de três tipos de corpos de prova que foram analisados por microscopia óptica com ampliação de 100 vezes e análise por difração de raios X. A figura 8 mostra um comparativo entre as microscopias verificadas nos corpos de prova da formulação A queimados à $1000^{\circ} \mathrm{C}$ e à $1200^{\circ} \mathrm{C}$. É possível verificar na figura $9 \mathrm{~b}$ ) uma maior formação de fase vítrea à temperatura de $1200^{\circ} \mathrm{C}$, devido ao maior brilho característico em relação a microscopia da figura 9 a), apesar da coloração mais escura.
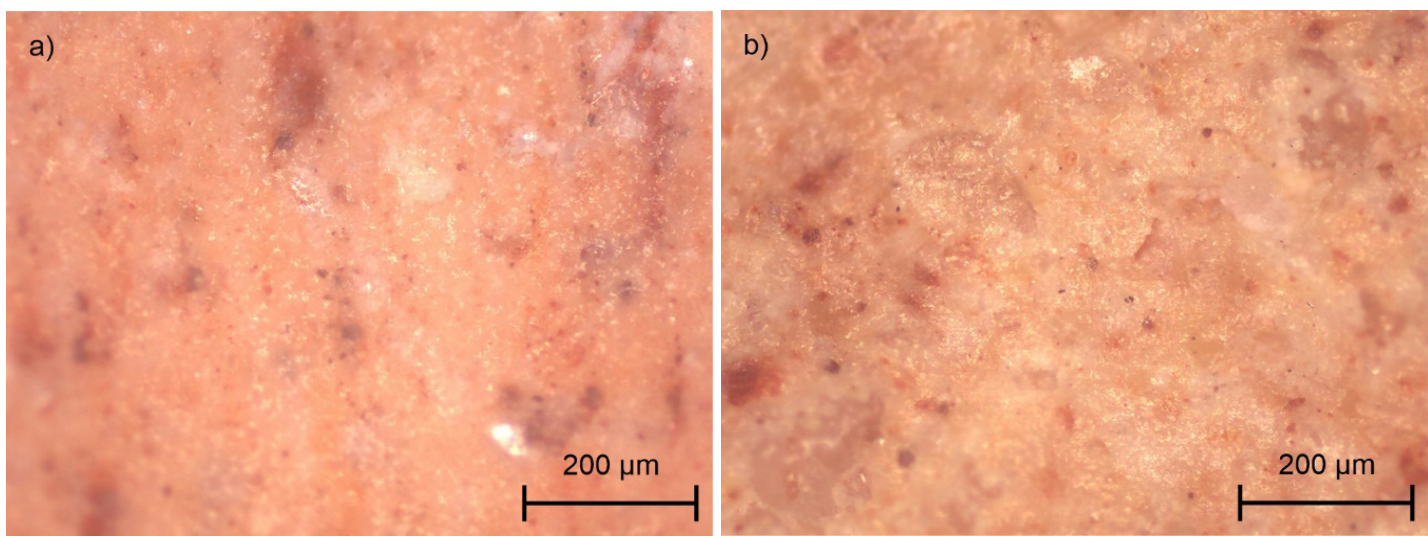

Fig. 9. Microscopia das formulações A nas temperaturas de $1000^{\circ} \mathrm{C}$ e $1200^{\circ} \mathrm{C}$

Com a adição de $10 \%$ de talco na argila, os ganhos de redução de porosidade e aumento de brilho vítreo foram ainda maiores. Na figura 10, é possível perceber uma grande diferença entre as superfícies das peças das formulações $\mathrm{A}$ e T10. A explicação para isto é que, além do $\mathrm{CaO}$, a presença de óxido de magnésio liberado pela descarbonização da dolomita do talco contribuiu para a uma sinterização mais efetiva da peça. Com a participação de dois tipos de óxidos fundentes na massa cerâmica, ocorreu uma maior densificação nas peças, o que proporcionou a obtenção da maior resistência à flexão e menor valor de absorção de água na formulação T10.

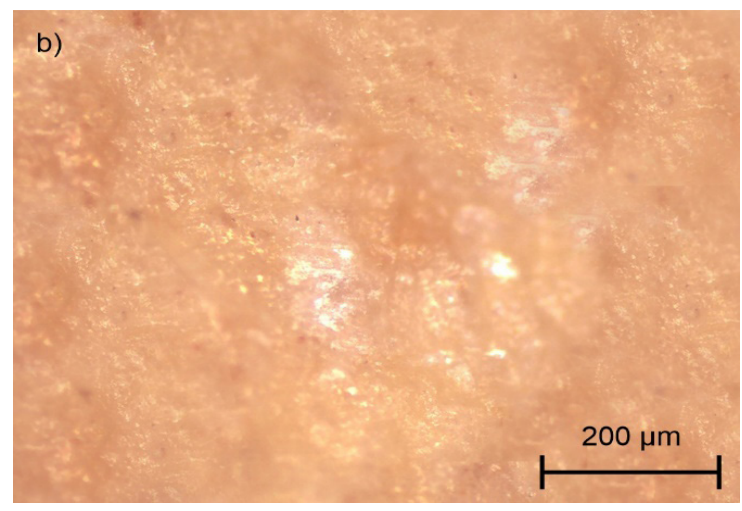

Fig. 10. Microscopia da formulação T10 na temperatura de $1200^{\circ} \mathrm{C}$ 
O ensaio de difração de raios $X$ foi realizado nos corpos de prova que apresentaram os melhores resultados de resistência à flexão. Além destes, foi ensaiado, também, um corpo de prova da formulação A queimado à temperatura de $1000^{\circ} \mathrm{C}$, para efeito de comparação. Em torno de $500{ }^{\circ} \mathrm{C}$, ocorre a transformação da caulinita em metacaulinita, conforme mostrado na curva termogravimétrica da figura 4. A metacaulinita é uma fase amorfa, com reflexões difusas e fracas, o que resulta em picos não detectáveis no DRX, conforme mostrado na figura 11. Assim, após análise dos picos encontrados na formulação padrão, verificou-se que todos os de maior intensidade eram referentes ao quartzo, sendo os dois primeiros, e principais, com distâncias interplanares $d=4,25 \AA$ e $d=3,34 \AA$. Estes valores corroboram com os catalogados por SANTOS (1989). O quartzo, apesar de promover boa estabilidade nas configurações geométricas da peça após a queima, é uma fase que não apresenta elevada resistência. Portanto, até a temperatura de $1000^{\circ} \mathrm{C}$, não ocorreu efetiva dissolução do quartzo na matriz cerâmica a ponto de promover a formação de novas fases cristalinas e de maior resistência, o que explica o baixo valor de 12,09 MPa de MRF encontrado.

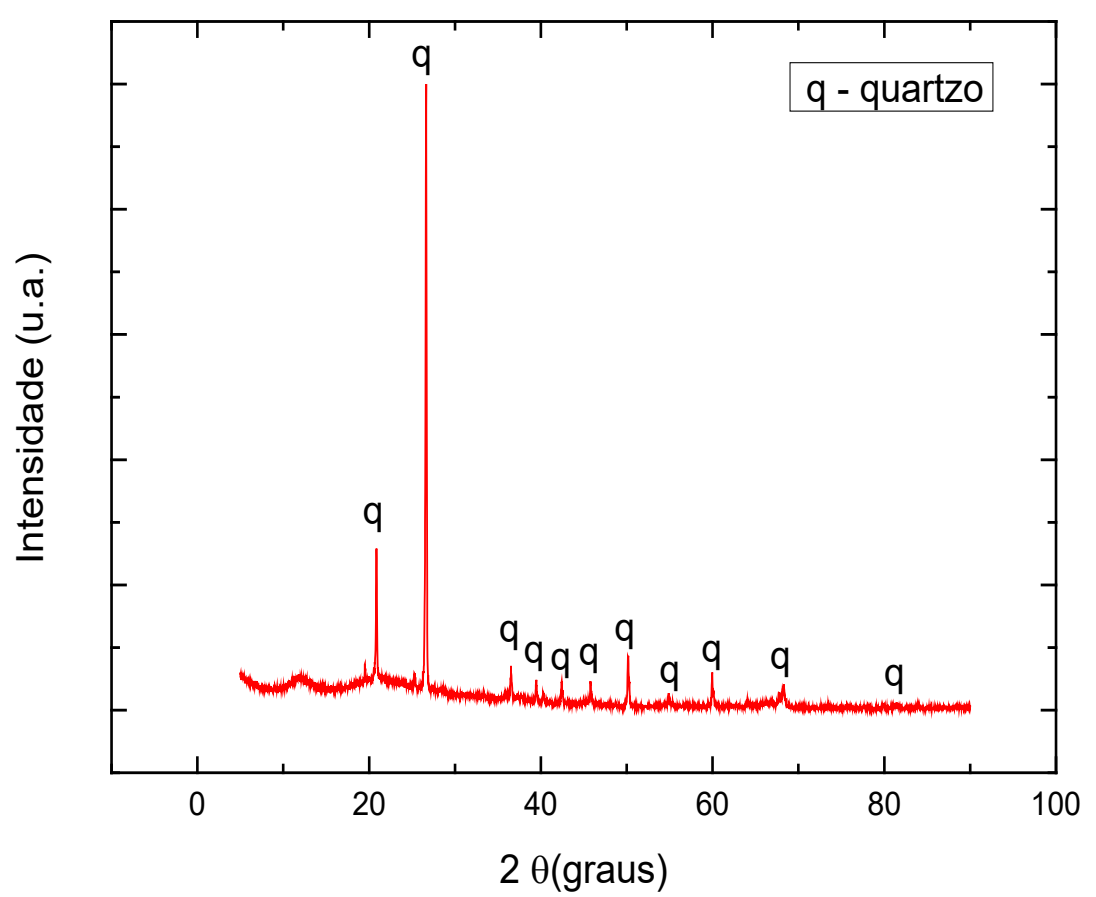

Fig. 11. Difratograma da formulação $A$ na temperatura de $1000^{\circ} \mathrm{C}$

Com o aumento da temperatura de queima até $1200^{\circ} \mathrm{C}$, aconteceu, como previsto, a formação de novas fases cristalinas resultantes da interação entre o quartzo dissolvido na fase líquida formada e os demais componentes da argila. Isto pode ser confirmado pelo novo percentual obtido para esta fase cristalina, em torno de $52,50 \%$ e não os $100,00 \%$ verificados na situação anterior. O aumento progressivo da temperatura de queima favoreceu o desenvolvimento de cristais até a obtenção da fase cristalina mulita, que possui grande resistência mecânica, devido a sua estrutura cristalina ortorrômbica, cujos três eixos cristalográficos são perpendiculares entre si (SANTOS et al., 2006). A obtenção de mulita na proporção estequiométrica de 2:1 foi favorecida pelo caráter triclínico da caulinita da argila base, que possui baixo grau de desordem estrutural (CORRÊA et al., 2008). O percentual de fase cristalina da mulita foi de $24,2 \%$. Além de quartzo e mulita, verificou-se a formação de uma terceira fase cristalina, a hematita. Isto corrobora com a análise macroestrutural da formulação $A$ na temperatura de $1200^{\circ} \mathrm{C}$, em que se verificou um significativo escurecimento dos corpos de prova. A figura 12 mostra a análise dos picos do difratograma de raios $\mathrm{X}$. 


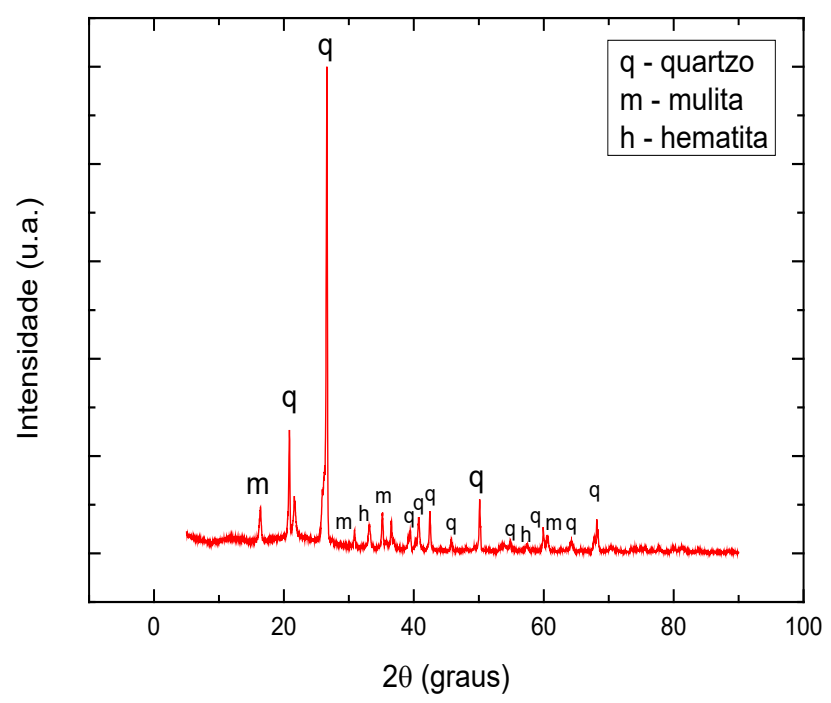

Fig. 12. Difratograma da formulação A na temperatura de $1200^{\circ} \mathrm{C}$

Na formulação T10, queimada na temperatura de $1200^{\circ} \mathrm{C}$, além da mulita e do quartzo, verificou-se a formação da enstatita ( $\left.\mathrm{MgO} \cdot \mathrm{SiO}_{2}\right)$, conforme explicado por Rodrigues Neto et al.(2014). A adição de talco à massa cerâmica fornece grande quantidade de átomos de magnésio provenientes dos silicatos e carbonatos constituintes deste mineral. Após a queima, como resultado da decomposição dos materiais, os óxidos de magnésio se recombinam com dióxido de silício formando enstatita com um percentual de $34,70 \%$ das fases cristalinas, conferindo assim uma maior resistência aos corpos de prova.

Além do óxido de magnésio, a descarbonização da dolomita do talco libera grande quantidade de óxido de cálcio ( $\mathrm{CaO})$, que também reage com o quartzo dissolvido, alumina e forma anortita, com um percentual de $24,81 \%$. O aumento da cristalização reduz ligeiramente a formação de mulita (16,85\%), e mais que dobra o percentual de cristobalita formada, chegando a $15,74 \%$. A formação de enstatita e o aumento percentual de $117,70 \%$ das fases de cristobalita resultaram numa maior resistência à flexão encontrada, com 39,92 MPa, resultante do maior ordenamento estrutural da cristobalita, através do rearranjo dos átomos de silício e oxigênio em um sistema cristalino tetragonal (SANTOS, 1989). O teor de quartzo foi reduzido para 7,90\%. A figura 13 mostra o difratograma da formulação T10.

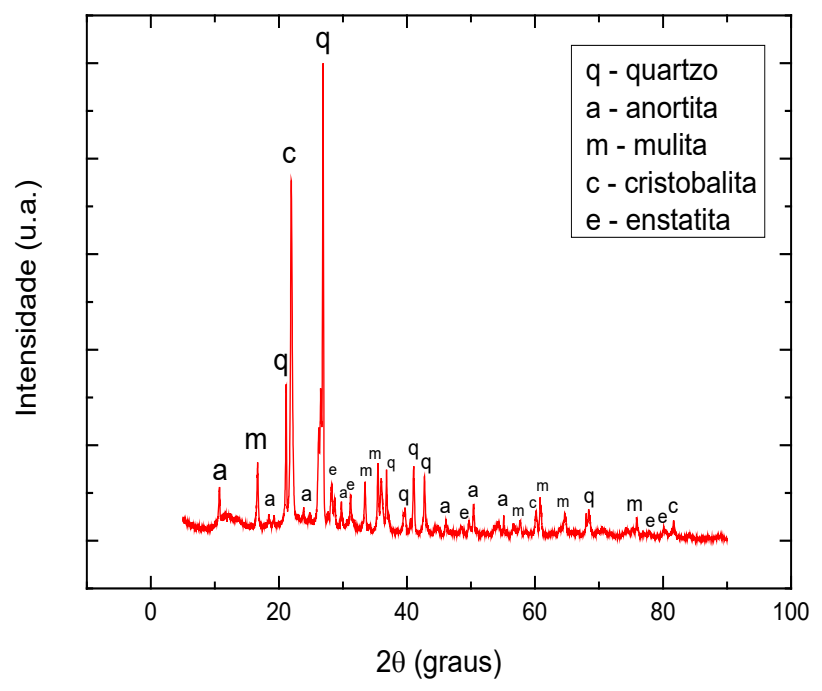

Fig. 13. Difratograma da formulação T10 na temperatura de $1200{ }^{\circ} \mathrm{C}$ 


\section{CONCLUSÕES}

A utilização de argila caulinítica, com propriedades refratárias, e materiais com grande percentual de carbonatos de cálcio e magnésio, de natureza fundente, levaram a grande formação de fase líquida em temperaturas mais elevadas. Isto resultou numa maior densificação das peças, aumentando a perda ao fogo devido a saída de $\mathrm{CO}_{2^{\prime}}$ reduzindo a porosidade aberta, diminuindo a absorção de água e assim aumentando a resistência à flexão dos corpos de prova. $\mathrm{O}$ aumento progressivo da temperatura de queima promoveu a formação de nova fases cristalinas como a cristobalita, resultante do polimorfismo do quartzo, e a mulita, resultante da recombinação dos átomos do quartzo dissolvido na matriz cerâmica com os átomos de alumina. Essas duas propiciariam aumento da MRF nas peças, sendo que, naquelas com os maiores percentuais de cristobalita, a resistência à flexão encontrada foi superior as das outras formulações.

Adição de talco contendo grande percentual de dolomita promoveu a formação de outras fases cristalinas durante à queima na temperatura de $1200^{\circ} \mathrm{C}$, resultantes da reação entre os óxidos de cálcio $(\mathrm{CaO})$ e magnésio $(\mathrm{MgO})$, alumina $\left(\mathrm{Al}_{2} \mathrm{O}_{3}\right)$ e do próprio quartzo $\left(\mathrm{SiO}_{2}\right)$, sendo elas: anortita $\left(\mathrm{CaAl}_{2} \mathrm{SiO}_{8}\right)$ e enstatita $\left(\mathrm{MgO} \cdot \mathrm{SiO}_{2}\right)$. Isso influenciou positivamente no módulo de resistência à flexão das peças, sendo observado em todas as formulações um aumento percentual relativo em relação à MRF da formulação $A$, sem adição dos minerais.

A formulação com o maior módulo de resistência à flexão verificado foi a T10, na temperatura de $1200{ }^{\circ} \mathrm{C}$, com um valor de 39,92 MPa. Nesta, também se obteve o menor valor de AA, com 4,13\%, permitindo a sua classificação como revestimento cerâmico do tipo Blla. As demais formulações que obtiveram esta classificação, foram: T5, T20 e MT5. Os resultados mostram que, dependendo da temperatura de queima utilizada, a formulação A pode ter melhor aplicabilidade técnica, que fornecem melhores resultados nas temperaturas de $1000^{\circ} \mathrm{C}$ e $1100^{\circ} \mathrm{C}$. À temperatura de $1200^{\circ} \mathrm{C}$, fica evidente o melhor desempenho resultante da adição de talco nas massas cerâmicas, obtendo revestimentos de qualidade superior.

\section{AGRADECIMENTOS}

Os autores agradecem à Fundação de Amparo à Pesquisa do Estado do Piauí (FAPEPI) e à Coordenação de Aperfeiçoamento de Pessoal de Nível Superior (CAPES) pelo apoio financeiro para a realização deste trabalho.

\section{REFERÊNCIAS}

ALMEIDA. M. I. et al. Environmental profile of ceramic tiles and their potential for improvement. Journal of Cleaner Production, v.131, p.583-593, 2016.

ANDRADE, P. M.; NETO, H. S. N.; MONTEIRO, S. N.; VIEIRA, C. M. F. Efeito da adição de fonolito na sinterização de argila caulinítica. Cerâmica (online). vol. 51, n. 320, p. 361-370, 2005.

ANFACER - Associação Nacional dos Fabricantes de Cerâmica para Revestimento, Louças Sanitárias e Congêneres. Overview 2018. Anfacer, 2018.

ARAÚJO, I. O.; SOUZA, A. G.; SANTOS, I. M. G.; Caracterização química de caulins de Junco do Seridó-PB. Cerâmica industrial, v. 17, n. 2, p. 36-38, mar./dez. 2014.

ASSOCIAÇÃO BRASILEIRA DE NORMAS TÉCNICAS. NBR 6459: Solo - Determinação do limite de liquidez. Rio de Janeiro, 2016. Versão corrigida: 2017.

ASSOCIAÇÃO BRASILEIRA DE NORMAS TÉCNICAS. NBR 7180: Solo - Determinação do limite de plasticidade. Rio de Janeiro, 2016. Versão corrigida: 2017.

ASSOCIAÇÃO BRASILEIRA DE NORMAS TÉCNICAS. NBR 7181: Solo: Análise granulométrica. Rio de Janeiro, 2016. Versão corrigida 2:2018.

ASSOCIAÇÃO BRASILEIRA DE NORMAS TÉCNICAS. NBR ISO 13006: Placas cerâmicas - Definições, classificação, características e marcação. Rio de Janeiro, 2020.

BIFFI, G. O grês porcelanato: manual de fabricação e técnicas de emprego. São Paulo: Faenza editrice do Brasil, 2002.

CONSTANTINO, A. O.; ROSA, S. E. S.; CORRÊA, A. R. Panorama do setor de revestimentos cerâmicos. BNDES, 2006.

CORREAA, M. M.; KER, J. C.; BARRÓN, J.; TORRENT, J.; FONTES, M. P. F.; CURI, N. Propriedades cristalográficas de caulinitas de solos do ambiente Tabuleiros Costeiros, Amazônia e Recôncavo Baiano. Revista Brasileira de Ciência do Solo, v. 32, n. 5, p. 1857-1872, 2008.

DO BRASIL, CPRM-SERVIÇO GEOLÓGICO. Mapa geológico do estado do Piauí. CPRM, 2006.

GARDOLINSKI, J. E.; MARTINS FILHO, H. P.; WYPYCH, F. Comportamento térmico da caulinita hidratada. Quím. Nova [online]. vol. 26 , n. 1, p.30-35. 2003. 
KLEIN, C.; DUTROW, B. Manual de Ciências dos Minerais. Porto Alegre: Bookman, 2012.

HAZEN, A. The filtration of public water-supplies. John Wiley \& Sons, 1905.

LLOP, J.; NOTARI, M.D.; NEBOT-DÍAZ, I.; BARRACHINA, E.; NUÑES, I.; CARD, J. B. A. Estudo da greisificação de composições de grés porcelânico formuladas com matérias-primas espanholas. Cerâmica Industrial, São Paulo, v.16, n. 5-6, p. 7-11, set./ dez. 2011.

MARINO, L. F. B.; BOSCHI, A. O. A Expansão Térmica de Materiais Cerâmicos Parte II: Efeito das Condições de Fabricação. Cerâmica Industrial, São Paulo, v.3, n. 3, p. 23-33, mai./jun. 1998.

MARINO, L. F. B.; MELCHIADES, F. G.; BOSCHI, A.O. A expansão térmica dos revestimentos cerâmicos parte V: efeitos da adição de talco. Cerâmica industrial, vol. 5, n. 5, p. 47-50, set./out. 2000.

MOTTA, J. F. M.; JÚNIOR, M. C.; TANNO, L. C. Panorama das matérias-primas utilizadas na indústria de revestimentos cerâmicos: desafios do setor produtivo. Cerâmica industrial, vol. 3, n. 4-6, p. 30-38, jul./dez. 1998.

MOTTA, J. F. M. et al. Rochas e Minerais Industriais. 2a . ed. São Paulo: [s.n.], 2008.

PFALTZGRAFF, P. A. S.; TORRES, F. S. M.; BRANDÃO, R. L. Geodiversidade doestado do Piauí. CPRM, Recife, 2010.

PINTO, M. F.; SOUSA, S. J. G.; HOLANDA, J. N. F. Efeito do ciclo de queima sobre as propriedades tecnológicas de uma massa cerâmica vermelha para revestimento poroso. Cerâmica, vol. 51, n. 319, p. 225-229, 2005.

RODRIGUES NETO, J. B.; HOTZA, D.; MORENO, R. Efeito da ativação mecânica de uma formulação de talco/caulim/alumina sobre o mecanismo e a cinética de formação de cordierita. Química Nova (Impresso), v. XY, p.1 - 5, 2014.

SANTOS, P. S. Ciência e tecnologia de argilas. 2. ed. São Paulo: Edgard Blücher, 1989.

SANTOS, H. S.; KIYOHARA, P.; COELHO, A. C. V.; SANTOS, P. S. Estudo por microscopia eletrônica das transformações durante a queima de argilas altamente aluminosas brasileiras. Cerâmica, vol. 52, p. 125-137, 2006.

SILVA, P. F. F. Análise quantitativa de fases em matérias-primas cerâmicas: desenvolvimento e validação de software com programação em Matlab adequada ao método de análise racional UFSC. 2015. Dissertação (Mestrado em Engenharia de Materiais) - Instituto Federal de Educação, Ciência e Tecnologia do Piauí, Teresina.

SOARES, R. A. L. Efeitos da Adição de Carbonatos em Formulações de Massa para Revestimento Cerâmico Utilizando matérias-primas do Piauí. Tese (Doutorado) - Universidade Federal do Rio Grande do Norte. Natal. 2010

SOARES, R. A. L. et al. Influência do teor de calcário no comportamento físico, mecânico e microestrutural de cerâmicas estruturais. Cerâmica industrial, vol. 15, n. 2, p. 38-42, mar./abr. 2010.

SOARES, R. A. L.; CASTRO, R. G. S.; NASCIMENTO, R.M. Comparação do desempenho da adição de carbonatos calcítico e dolomítico em massa cerâmica de revestimento queimada em forno industrial. Cerâmica industrial, vol. 20, n. 5-6, p. 16-24, set./dez. 2016.

SOUSA, S. J. G., HOLANDA, J. N. F. Formulação de massas de revestimento cerâmico poroso (BIII) com matérias-primas do norte fluminense. Cerâmica industrial, vol. 11, n. 4, p. 29-33, jul./ago. 2006.

VIEIRA, C. M. F.; SOARES, J. B.; MONTEIRO, S. N. Desenvolvimento de massas de revestimento cerâmico com argila caulinítica e nefelina sienito. Cerâmica (online). vol. 54, n. 330, p.184-192. 2008. 